\title{
Using Video to Evaluate Depth and Velocity Selection by Arctic Grayling (Thymallus arcticus) in Pools of an Engineered Tundra Stream
}

\author{
Cody Kupferschmidt, ${ }^{1,2}$ Fred Noddin, ${ }^{3}$ David Z. Zhu ${ }^{1}$ and William M. Tonn ${ }^{3}$
}

(Received 13 November 2017; accepted in revised form 9 October 2018)

\begin{abstract}
We evaluated pool use by Arctic grayling (Thymallus arcticus) in an engineered stream in the Canadian Barrenlands at the summer background flow $(1.0 \mathrm{l} / \mathrm{s})$ and at enhanced flows $(9.9$ 1/s and $21.9 \mathrm{l} / \mathrm{s})$ similar to those during the spring spawning period. We used an acoustic Doppler velocimeter to measure and map out point velocities (horizontal and vertical) in five study pools. The positions of adult Arctic grayling were monitored for each flow condition using visual surveys and a novel video assessment technique. Although fish mobility limited pool selection at the summer background flow, the highest use of pools by fish during enhanced flows occurred where pool designs incorporated scour holes or downstream sills to provide larger amounts of relatively deep water. Within those pools, grayling selected for locations with depths between $0.20 \mathrm{~m}$ and $0.30 \mathrm{~m}$ and near-zero vertical velocities $(-0.02 \mathrm{~m} / \mathrm{s}$ to $0.04 \mathrm{~m} / \mathrm{s})$. Fish selected near-zero horizontal velocities $(0.00 \mathrm{~m} / \mathrm{s}$ to $0.04 \mathrm{~m} / \mathrm{s})$ for resting and higher velocities $(0.12 \mathrm{~m} / \mathrm{s}$ to $0.20 \mathrm{~m} / \mathrm{s})$ for feeding. In contrast, grayling tended to show local avoidance of areas with horizontal velocities above $0.2 \mathrm{~m} / \mathrm{s}$ or vertical velocities above $0.04 \mathrm{~m} / \mathrm{s}$. Although findings are likely site specific, our study contributes towards the development of size, depth, and velocity criteria for Arctic grayling habitat; this information can promote effective designs for habitat compensation and fish passage projects. We also present a novel video monitoring method that can be easily deployed at remote locations.
\end{abstract}

Key words: Arctic grayling; habitat selection; ecohydraulics; video monitoring; natural channel design; Thymallus arcticus

RÉSUMÉ. Nous avons évalué l'utilisation de bassins par l'ombre arctique (Thymallus arcticus) dans un cours d'eau artificiel aménagé dans la lande canadienne au débit de base estival (1,0 1/s) et à des débits accrus $(9,9 \mathrm{l} / \mathrm{s}$ et 21,9 1/s) semblables à ceux qui existent pendant la période de frai du printemps. Nous avons employé un courantomètre acoustique Doppler pour mesurer et tracer les vitesses ponctuelles (horizontales et verticales) de cinq bassins à l'étude. Les positions des ombres arctiques adultes ont été surveillées pour chaque débit à l'aide de contrôles visuels et d'une nouvelle technique d'évaluation par vidéo. Bien que la mobilité des poissons ait eu pour effet de limiter la sélection du bassin dans le cas du débit de base estival, la plus grande utilisation des bassins par les poissons en présence de débits accrus a été remarquée dans les bassins dont la conception comprenait des fosses d'affouillement ou des seuils aval présentant de plus grandes quantités d'eau relativement profonde. Dans ces bassins, les ombres arctiques ont sélectionné des emplacements ayant des profondeurs variant de $0,20 \mathrm{~m}$ à $0,30 \mathrm{~m}$ et des vitesses verticales proches de zéro (de $0,02 \mathrm{~m} / \mathrm{s}$ à $0,04 \mathrm{~m} / \mathrm{s}$ ). Les poissons optaient pour des vitesses horizontales proches de zéro (de $0,00 \mathrm{~m} / \mathrm{s}$ à $0,04 \mathrm{~m} / \mathrm{s}$ ) pour se reposer et pour des vitesses accrues (de $0,12 \mathrm{~m} / \mathrm{s}$ à $0,20 \mathrm{~m} / \mathrm{s}$ ) pour manger. En revanche, l'ombre avait tendance à éviter localement les zones aux vitesses horizontales supérieures à $0,2 \mathrm{~m} / \mathrm{s}$ ou aux vitesses verticales supérieures à $0,04 \mathrm{~m} / \mathrm{s}$. Même si ces constatations sont probablement spécifiques à ce site, notre étude contribue à la formulation de critères pour la taille, la profondeur et la vitesse de l'habitat de l'ombre arctique. Ces renseignements peuvent favoriser la conception efficace de projets de compensation d'habitats et de passages pour poissons. Nous présentons également une nouvelle méthode de surveillance vidéo qui peut être facilement déployée dans des endroits éloignés.

Mots clés : ombre de l'arctique; sélection de l'habitat; écohydraulique; surveillance vidéo; conception de canal naturel; Thymallus arcticus

Traduit pour la revue Arctic par Nicole Giguère.

\section{INTRODUCTION}

Freshwater ecosystems, which support numerous species at risk (MEA, 2005), are among those most significantly impacted by human activity. Better designs for stream engineering, habitat restoration, and fish passage projects are needed to help mitigate human impacts. Despite numerous publications available on the technical design of natural channels (e.g., Copeland et al., 2001; USDA/NRCS, 2007) and fish passage projects (e.g., Clay, 1995; FAO/ DVWK, 2002), many nature-like channels designed to pass fish are still built based on ad-hoc information. There is a clear need to develop species-specific design guidelines based on hydraulic studies, controlled experiments with

\footnotetext{
${ }^{1}$ Department of Civil and Environmental Engineering, University of Alberta, Edmonton, Alberta T6G 1H9, Canada

${ }^{2}$ Corresponding author: codykupf@gmail.com

${ }^{3}$ Department of Biological Sciences, University of Alberta, Edmonton, Alberta T6G 1H9, Canada

(C) The Arctic Institute of North America
} 
fish, and detailed field studies, including field manipulations (Katopodis et al., 2001; Rosenfeld, 2003).

In contrast with historical fishway designs that used technical structures constructed from concrete, metal, wood, and fiberglass (Katopodis et al., 2001), many modern naturelike fishways use natural materials such as rock, gravel, and timber, and aim to mimic the width, cross-sectional area, and in-stream structures of natural streams. The implementation of nature-like fishways has been very successful, despite the limited availability of design guidelines. These fishways generally have higher fish passage rates and pass more species of fish than conventional fishways (Bunt et al., 2012).

While nature-like fishways have been built to pass Arctic grayling, Thymallus arcticus (e.g., Courtice et al., 2014, 2016; Cahill et al., 2015), there are no species-specific guidelines available; however, European guidelines on pool size and depth exist for the closely related European grayling, Thymallus thymallus (FAO/DVWK, 2002).

In fall 2012, Diavik Diamond Mines Inc. (DDMI) completed a habitat compensation project in the Barrenlands region of northern Canada. Much of the existing channel of West Island Stream (WIS) was re-engineered to increase stream length, reduce overall channel slope, and incorporate in-stream structures to promote fish passage. The goal of the project was to provide improved access and habitat connectivity to and through WIS for native fishes, particularly Arctic grayling, to travel to and from potential fish spawning habitat (MacNeill and Strong, 2004; Courtice et al., 2016).

This compensation project offered the unique opportunity to assess the hydraulics of a natural channel design and evaluate the effects of hydraulic structures on fish habitat use in the field (rather than on a laboratoryscale model). To provide flow conditions representative of different times in the hydrologically dynamic open-water season of WIS, we used a diesel pump to manipulate the flow of WIS. Because Arctic grayling are neither native to or had yet colonized the re-engineered WIS, we also introduced Arctic grayling from a nearby system into the steepest section of the stream to examine their behavior. The objectives of our research were to understand the use of pools by Arctic grayling and, within those pools, their selection of locations by depth and velocity under three different flow conditions.

We assessed fish habitat use and selection using a novel technique that combined spatially referenced video footage filmed from above with detailed depth and three-dimensional velocity measurements for each of five study pools.

\section{METHODS}

\section{Study Site}

WIS is located at $64.527^{\circ} \mathrm{N}, 110.436^{\circ} \mathrm{W}$ in the Southern Arctic Ecozone (CCEA 2014), approximately $8 \mathrm{~km}$ west of the DDMI mine site (Fig. 1). The site lies approximately

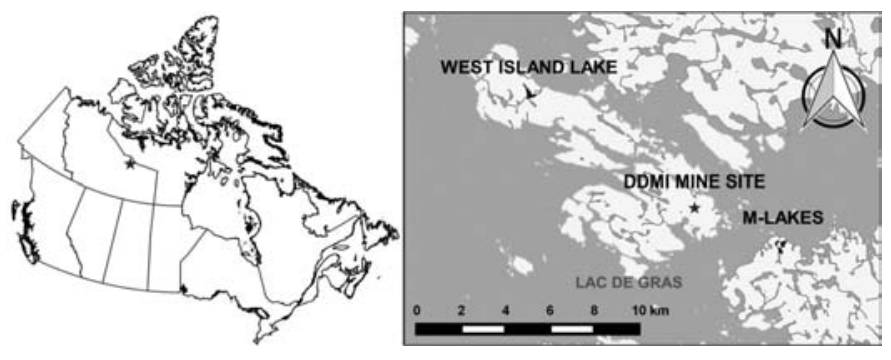

FIG 1. Left: Location of study site (star) in Canada. Right: Locations of West Island Lake and M-Lakes (black fill) in relation to Lac de Gras (grey) and the Diavik Diamond Mine Inc. (DDMI) mine site (star). West Island Lake is the headwater source of West Island Stream study site; Arctic grayling used in this study were captured from M-Lakes. Map data from GeoBase (2014).

$100 \mathrm{~km}$ north of the tree line in a semi-arid region (the Barrenlands) that receives about $250 \mathrm{~mm}$ of precipitation annually, approximately half of which falls as snow (Environment Canada, 1991). Typical of Barrenland streams (Jones et al., 2003), after being frozen solid for more than seven months, freshet in WIS usually occurs in early June, with flows declining rapidly afterwards and pools becoming hydraulically separated by mid-tolate summer (Courtice et al., 2014, 2016). WIS is the only outlet of West Island Lake (WIL), a 13.65 ha headwater lake with a direct catchment area of 30.08 ha (Baki et al., 2012). The stream flows from WIL into the $577 \mathrm{~km}^{2}$ Lac de Gras (Wedel et al., 1988).

In September 2011, WIS had a length of $430 \mathrm{~m}$ with an overall slope of $1.8 \%$ (Ramsey and Walker, 2012). The downstream-most $40 \mathrm{~m}$ section of WIS, however, consisted of small cascades and steep, braided channels that ranged in slope from $9.1 \%$ to $12.8 \%$, creating a barrier to upstream passage by fish, including Arctic grayling (Ramsey and Walker, 2012; Noddin, 2017). DDMI therefore initiated the West Island habitat compensation project to help offset aquatic impacts due to mining activities. In late summer 2012, the downstream-most $310 \mathrm{~m}$ of WIS was channelized, the steep lower section was rerouted and lengthened to reduce maximum channel slope to $5 \%$, and in-stream structures, including rock weirs, choke-pools, and rock ramps, were installed (Courtice et al., 2016). Postconstruction, it was deemed that the downstream-most $100 \mathrm{~m}$ would still be the most challenging and energetically demanding section for fish to ascend and, as a result, the most crucial area in which to provide resting pool habitats. Our research thus focused on evaluating the design and habitat selection within the pools in this section.

\section{Arctic Grayling}

Arctic grayling are spring-spawning freshwater salmonids native to the Canadian North (Northcote, 1995). Many grayling overwinter in adjacent lakes, then migrate into small Barrenland streams to spawn following the peak flows of spring freshet, subsequently returning to lakes before summer flows decline to near-zero (Jones et al., 2003). Studies on burst and cruising speed suggest 


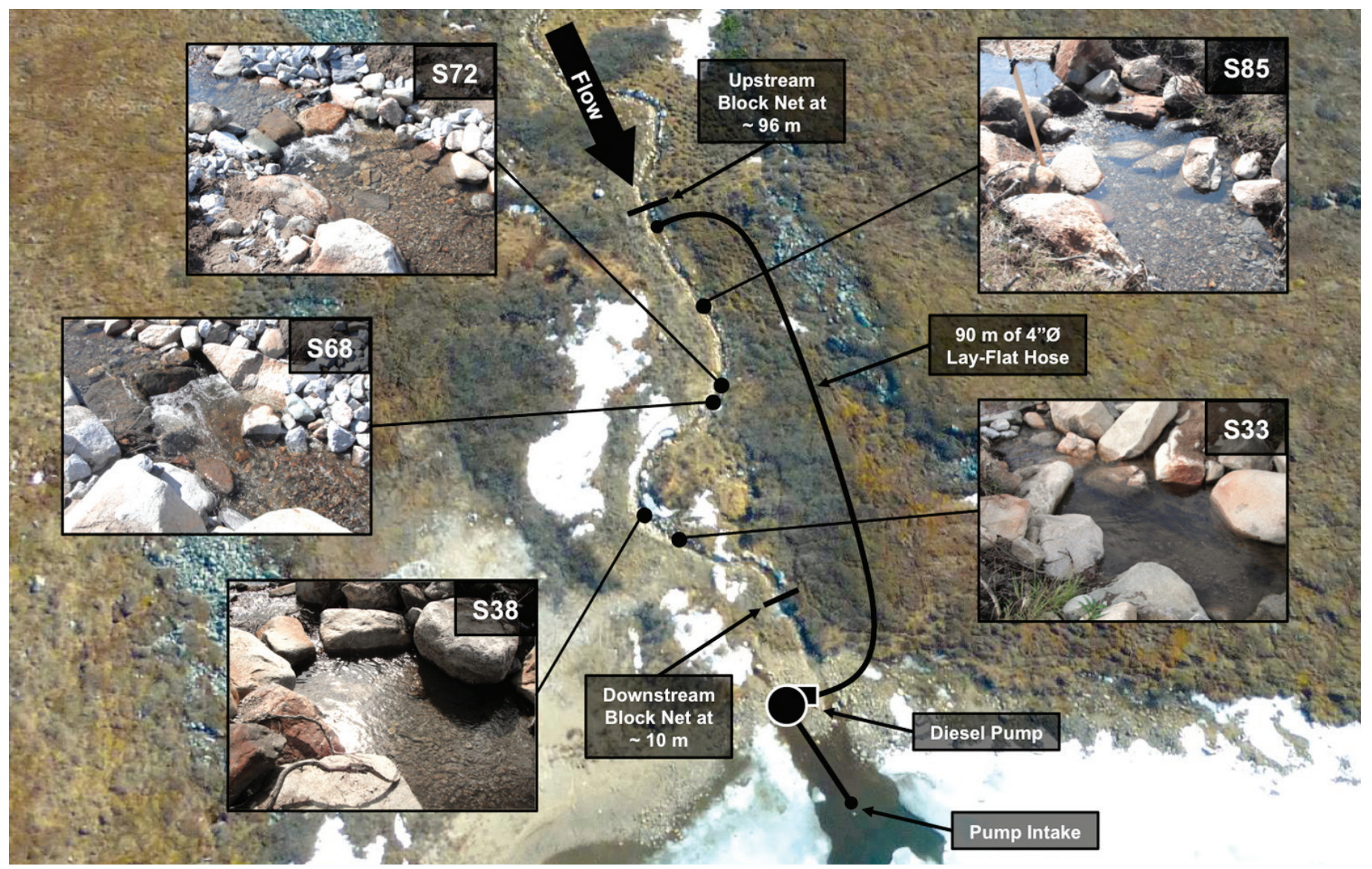

FIG. 2. Experimental setup for the West Island Stream flow manipulation experiment, including locations of the five study pools. Insets are photos of each study pool at $9.9 \mathrm{l} / \mathrm{s}$.

that these fish are moderately strong swimmers (Jones et al., 1974), but select low-velocity pools or stream margins adjacent to swifter currents for foraging and resting (Hughes and Dill, 1990; Hughes, 1992a, b), occupying deeper water as they grow (DenBeste and McCart, 1984; Jones and Tonn, 2004).

Arctic grayling have been observed spawning below in-stream structures in streams near the study site (Courtice et al., 2014), and it was expected that adult Arctic grayling would primarily use the reconfigured WIS as spawning habitat (MacNeill and Strong, 2004; Ramsey and Walker, 2012). Postmodification surveys of WIS revealed a single adult Arctic grayling detected one year later, and two juveniles detected in the second year, 2014 (F. Noddin, unpubl. data). At the time of the 2014 assessment, no spawning activity was evident. Spawning generally occurs during the spring to early summer period, with instream discharge typically ranging from 10 to 25 1/s (Courtice et al., 2016).

\section{Discharge and Temperature Data}

To determine discharge we measured velocity at stream cross-sections using a FlowTracker (SonTek) acoustic Doppler velocimeter (ADV). We calculated discharge using the area-velocity method (Harrelson et al., 1994); because of the shallow depth and narrow width of WIS, a minimum of 8 cells was used and measurements where the discharge uncertainty exceeded $25 \%$ were discarded. Uncertainty was calculated using working versions of the ISO Standard 748 and United States Geological Survey (USGS) methods provided in the SonTek/YSI FlowTracker Technical Manual (2007). Diver data loggers (Schlumberger Water Services) were used to record hydrostatic pressure, barometric pressure, and water temperature. We developed stage (water depth) vs. discharge rating curves and used these curves to convert hydrostatic pressure data into a discharge data set with a resolution of $10 \mathrm{~min}$.

\section{Hydraulic Evaluation}

We focused on five pools in the downstream-most $100 \mathrm{~m}$ of WIS. Each study pool was located immediately downstream of an in-stream fish passage structure and was identified as having a high potential for resting habitat for Arctic grayling. Pools were named based on the location of the closest upstream structure using the format "S-XX," where "S" stands for structure and "XX" corresponds to the stream thalweg distance $(\mathrm{m})$ to the structure from the mouth of WIS (Fig. 2). Pool S33 was downstream of a rock ramp, pool S38 was downstream of a choke-pool structure, and pools S68, S72, and S85 were downstream of rock weirs. Under extreme low flow, structures S68 and S85 could also 
operate as choke-pool structures. The designs of pools S33 and S38 incorporated downstream control structures and promoted the formation of scour holes.

To evaluate the hydraulics of each pool, we specified sampling points on a $0.1 \mathrm{~m} \times 0.1 \mathrm{~m}$ horizontal plane and collected three-dimensional velocity measurements at $60 \%$ of the water depth for each sampling point using a FlowTracker ADV. We also measured the water depth at each sampling point and recorded top of bank locations at each cross-section for every study pool. A bubble level attached to the wading staff of the ADV ensured accuracy for vertical velocity measurements, while $\mathrm{x}$ and $\mathrm{y}$ velocities were based on aligning the sensor in the perceived upstream direction when taking a measurement.

Hydraulic measurements were taken at three different flow conditions: the natural background flow for early July (1.0 1/s) and two artificially increased flows $(9.9$ and $21.9 \mathrm{l} / \mathrm{s})$ intended to replicate natural flows at the study site during the spawning period. We used a diesel centrifugal pump (Gorman-Rupp 10 Series Model 14A2-TS2 S/G) and $90 \mathrm{~m}$ of 4-inch $(10.2 \mathrm{~cm})$ diameter, lay-flat hosing to pump water from Lac de Gras into the lower $110 \mathrm{~m}$ reach of WIS (Fig. 2).

\section{Fish Monitoring}

For each of the three flow conditions, 30 adult grayling were captured from nearby lakes (M-Lakes; Fig. 1) and transported to WIS via helicopter. A total of 90 adult grayling were used over the course of the three flows. We stocked six fish in each of the study pools; except for S68, which received no fish; instead, six fish were placed in pool S60 as part of a complementary study. This number was within the range of fish observed in pools of similar sizes at nearby sites during the spawning period (C. Kupferschmidt, pers. obs.). Following a 1-hour acclimation period after stocking, fish in the study pools were monitored for 48 hours. We placed block nets approximately $10 \mathrm{~m}$ upstream of the most-upstream pool and $20 \mathrm{~m}$ downstream of the most-downstream study pool to ensure that fish remained within the study reach throughout the duration of the study (Fig. 2).

To evaluate the behaviour and position of fish, we conducted visual surveys of the study pools by an observer wearing polarized sunglasses; surveys $(18-22$ per flow condition) were conducted at approximately $60 \mathrm{~min}$ intervals when it was logistically possible and safe to access the study site, typically between 0800 and $1800 \mathrm{hrs}$. For each survey, we recorded the number of Arctic grayling present in a pool and their specific location within a pool by marking the location of fish onto photos of the pools. To obtain higher resolution spatial data on fish location, we used GoPro cameras (HERO, HERO2, and HERO3) to record videos of each pool under each flow condition. We generally deployed cameras when fish were present in a given pool, but cameras were otherwise deployed in the early afternoon.

Each camera lens was calibrated for distortion using the OpenCV image processing library (Bradski, 2000, http://opencv.org) and Python version 2.7.5. The built-in OpenCV function cv2.findChessboardCorners was used to identify corners in a video of a $10 \times 7$ checkerboard pattern and cv2.calibrateCamera was used to calculate the intrinsic camera matrix and radial and tangential distortion coefficients (for more information see http://opencv.org documentation). Correcting for radial distortion was especially important for the GoPro cameras because of their fisheye lenses.

The resultant camera matrix was a $3 \times 3$ matrix containing the focal length in the $\mathrm{x}$ and $\mathrm{y}$ direction $\left(f_{x}, f_{y}\right)$ and the optical centres in the $\mathrm{x}$ and $\mathrm{y}$ direction $\left(c_{x}, c_{y}\right)$.

$$
\text { camera matrix }=\left[\begin{array}{ccc}
f_{x} & 0 & c_{x} \\
0 & f_{x} & c_{y} \\
0 & 0 & 1
\end{array}\right]
$$

Using the calibrated camera parameters, we projected the three-dimensional, local sampling grid coordinates on top of videos of each of the pools using the OpenCV function cv2.projectPoints (Fig. 3). The advantage of re-projection of the sampling grid rather than correcting the image is that data near the edge of images are not lost because of cropping. For each video, the translation and rotation vectors were manually determined by fitting the measured pool bank field data to the video pool banks. Re-projecting the sampling grid allowed us to compare fish locations with the measured hydraulic data.

For each pool and flow condition, we sampled the video at one frame per five sec for $10 \mathrm{~min}$ of video data (120 frames per pool and flow condition). In each video frame, fish were represented as a line and were identified manually by clicking the tips of their nose and caudal fin (Fig. 3). To calculate the number of fish present in each sampling cell for each frame, we determined locations where the line representing the fish intersected a sampling cell and then calculated the mean number of fish per sampling cell over the entire period.

To compare the available locations (sampling cells) with the locations used by fish, we looked at five parameters: $\mathrm{x}$ velocity, y velocity, $\mathrm{z}$ velocity, depth, and horizontal velocity magnitude $(\bar{V})$, calculated as $(\bar{V})=\sqrt{u^{2}+v^{2}}$, where $u$ and $v$ are the velocities at a given sampling point in the $\mathrm{x}$ and y directions, respectively.

\section{Statistical Methods}

To compare the number of fish present in each pool during the visual fish surveys, we performed a one-way analysis of variance (ANOVA), combined with a Tukey honest significant difference (HSD) test between pools for each flow condition.

To assess depth and velocity selection by Arctic grayling, we grouped the available and used habitat cells into histogram bins. Selection was defined as a higher usage rate than habitat availability rate for a given histogram bin, 


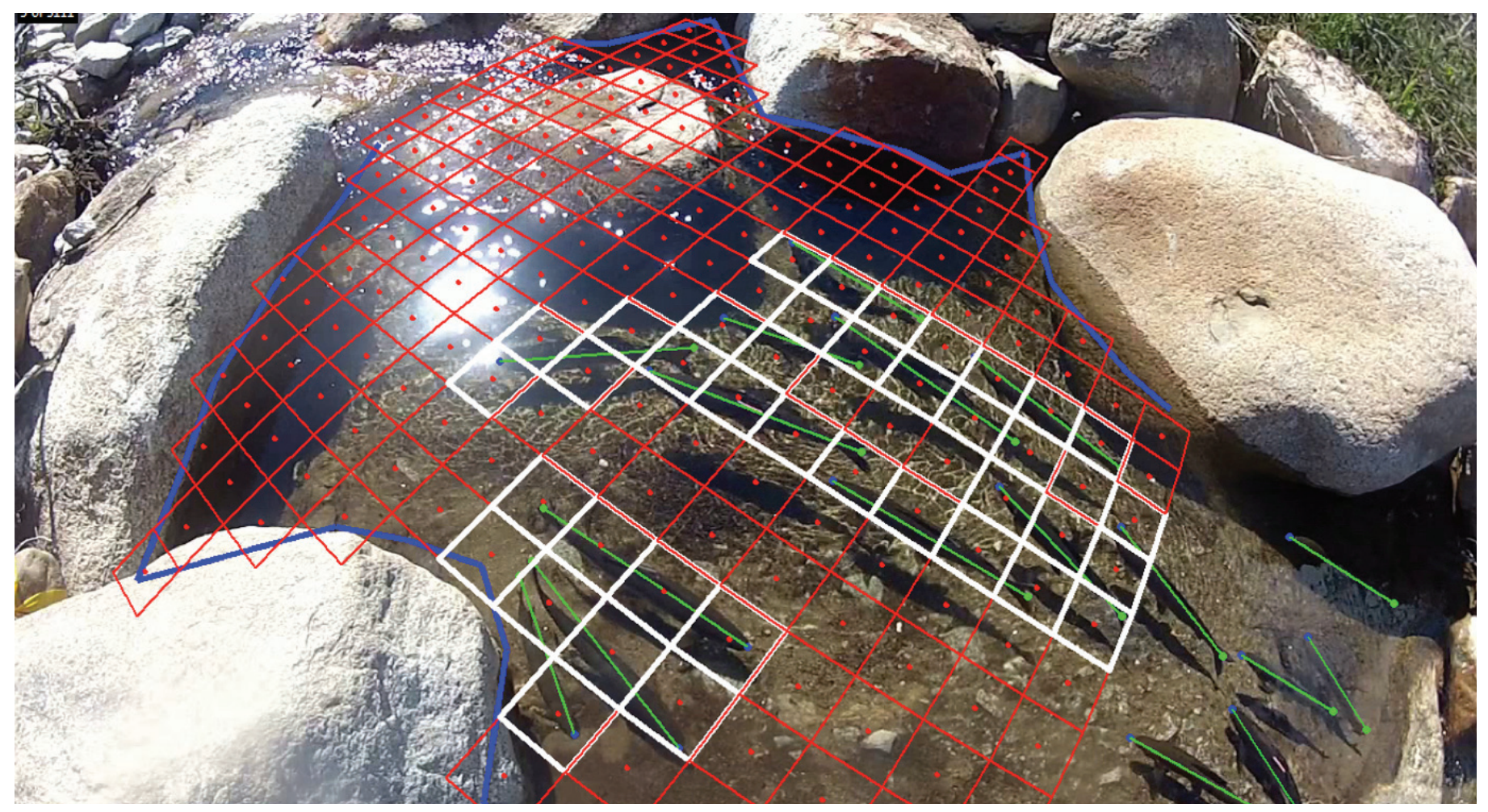

FIG. 3. Video frame shown for pool S33 with fish identified and sampling grid projected on frame using custom software (see text for details). Banks are shown in blue, fish are in green, sampling cells are in red, and sampling cells with fish present are in white.

while avoidance was defined as a lower usage rate than habitat availability rate (Rogers and White, 2007). Note that as defined, avoidance represents the local avoidance of in-pool habitat only, since extensive additional habitat available in WIS was not used during the studies. Pearson's chi-squared test was used to test for significant differences between used and available habitat. For significant differences, post-hoc multiple pairwise comparisons were performed for each histogram bin using a Bonferonni correction factor.

\section{RESULTS}

Using the diesel pump, we were able to obtain flows much higher than the natural July flow rate of $1.0 \mathrm{l} / \mathrm{s}$ during both manipulations 1 (9.9 1/s) and $2(21.9 \mathrm{l} / \mathrm{s})$ (Table 1). Stream temperatures during the two flow manipulations were $2.6^{\circ} \mathrm{C}$ cooler than the natural flow condition because of the addition of cooler water from Lac de Gras (Table 1). Although mean fish length varied significantly between the natural and manipulated flows, the maximum difference in mean fish length between trials $(4 \mathrm{~cm})$ was considered negligible for velocity selection, because the difference in sustained swimming velocity for a 29 and $33 \mathrm{~cm}$ fish is less than $0.05 \mathrm{~m} / \mathrm{s}$ (Jones et al., 1974).

Fish mobility appeared to be limited at $1.0 \mathrm{l} / \mathrm{s}$ and most fish stayed in the pool in which they were stocked (particularly S33, S38, and S85). Visual observations showed fish struggling to move between pools, and two deaths occurred when fish became stranded in shallow water. The steep rock-ramp structure between pool S33 and pool S38 appeared to act as a barrier to upstream passage. At 9.9 and 21.9 1/s there was a general trend of downstream movement, although there did not appear to be any barriers to upstream or downstream fish passage, and fish were observed travelling in both upstream and downstream directions throughout the entire study reach (Noddin, 2017). During flow manipulation 2 , a fox removed one fish.

At $1.0 \mathrm{l} / \mathrm{s}$ there was a significant difference $\left[\mathrm{F}_{4,85}=644\right.$, $p<0.01]$ in the number of fish between pools (Tables 2 and 3). Pool S85 contained the most fish, while S33 and S38 contained significantly more fish than the remaining pools. Pool S72 contained significantly less fish than all pools except S68, which was not stocked with fish. At $9.9 \mathrm{l} / \mathrm{s}$, there was also a significant $\left[\mathrm{F}_{4,105}=1318\right.$, $p<0.01$ ] difference between pools (Tables 2 and 3), with S33 containing significantly more fish than the other pools, followed by S38. During the visual fish surveys, no fish were observed in any of the other pools (Table 2). At $21.9 \mathrm{l} / \mathrm{s}$, pools also showed a significant difference $\left[\mathrm{F}_{4,95}=634\right.$, $p<0.01$, with $\mathrm{S} 33$ containing significantly more fish than the other pools (Tables 2 and 3). Very few fish were observed in pools S38, S72, and S85, while no fish were observed in S68. No significant difference was found between any of these pools. At 9.9 and $21.9 \mathrm{l} / \mathrm{s}$, visual observations showed multiple fish resting in a pool downstream of S33 that was not evaluated as part of the study.

At $1.0 \mathrm{l} / \mathrm{s}, \mathrm{S} 33$ and S38 were the only two pools with large areas where water depths exceeded 0.08 m (Fig. 4), 
$108 \cdot$ C. KUPFERSCHMIDT et al.

TABLE 1. Summary of conditions during the flow manipulation experiment in West Island Stream. Each flow condition was run continuously for 48 hours, beginning at the start time.

\begin{tabular}{lcccc}
\hline \hline Flow condition & Start time & Mean flow $(1 / \mathrm{s})$ & Mean water temperature $\left({ }^{\circ} \mathrm{C}\right)$ & Mean fish length $(\mathrm{mm})$ \\
\hline Natural Condition & 6 July 2014 14:30 & $1.0(\mathrm{SD}=0.1)$ & $12.8(\mathrm{SD}=3.1)$ & $330(\mathrm{SD}=32)$ \\
Manipulation 1 & 10 July 2014 18:30 & $9.9(\mathrm{SD}=1.5)$ & $10.2(\mathrm{SD}=1.3)$ & $300(\mathrm{SD}=32)$ \\
Manipulation 2 & 13 July 2014 19:00 & 21.9 $(\mathrm{SD}=2.3)$ & $10.2(\mathrm{SD}=1.5)$ & $290(\mathrm{SD}=39)$ \\
\hline \hline
\end{tabular}

TABLE 2. Mean number of fish in each study pool in West Island Stream during visual fish surveys $(\mathrm{n}=$ number of visual fish surveys conducted under each flow condition). Pool S68 was not stocked with fish. All other pools were stocked with six fish.

\begin{tabular}{|c|c|c|c|c|c|}
\hline Flow condition & Pool S33 & Pool S38 & Pool S68 & Pool S72 & Pool S85 \\
\hline $\begin{array}{l}\text { Natural condition } \\
\quad(\mathrm{n}=18)\end{array}$ & $\begin{array}{c}5.3 \\
(\mathrm{SD}=0.8)\end{array}$ & $\begin{array}{c}5.6 \\
(\mathrm{SD}=0.5)\end{array}$ & $\begin{array}{c}0.0 \\
(\mathrm{SD}=0.0)\end{array}$ & $\begin{array}{c}3.0 \\
(\mathrm{SD}=0.0)\end{array}$ & $\begin{array}{c}5.9 \\
(\mathrm{SD}=0.2)\end{array}$ \\
\hline $\begin{array}{l}\text { Manipulation } 1 \\
(\mathrm{n}=22)\end{array}$ & $\begin{array}{c}18.9 \\
(\mathrm{SD}=2.3)\end{array}$ & $\begin{array}{c}1.5 \\
(\mathrm{SD}=0.8)\end{array}$ & $\begin{array}{c}0.0 \\
(\mathrm{SD}=0.0)\end{array}$ & $\begin{array}{c}0.0 \\
(\mathrm{SD}=0.0)\end{array}$ & $\begin{array}{c}0.0 \\
(\mathrm{SD}=0.0)\end{array}$ \\
\hline $\begin{array}{l}\text { Manipulation } 2 \\
\quad(\mathrm{n}=20)\end{array}$ & $\begin{array}{c}11.1 \\
(\mathrm{SD}=1.8)\end{array}$ & $\begin{array}{c}0.2 \\
(\mathrm{SD}=0.4)\end{array}$ & $\begin{array}{c}0.0 \\
(\mathrm{SD}=0.0)\end{array}$ & $\begin{array}{c}0.1 \\
(\mathrm{SD}=0.2)\end{array}$ & $\begin{array}{c}0.2 \\
(\mathrm{SD}=0.5)\end{array}$ \\
\hline
\end{tabular}

TABLE 3. Difference in mean number of fish between study pools in West Island Stream during visual fish surveys. * denotes significance $(p<0.05)$ based on Tukey's HSD. The mean number of fish between pools may differ slightly from the numbers in Table 2 due to rounding.

\begin{tabular}{|c|c|c|c|c|c|}
\hline Flow condition & Pool & S38 & S68 & S72 & S85 \\
\hline \multirow[t]{4}{*}{ Natural condition $(1.0 \mathrm{l} / \mathrm{s})$} & S33 & 0.3 & $5.3^{*}$ & $2.3^{*}$ & $0.7^{*}$ \\
\hline & S38 & - & $5.6^{*}$ & $2.6^{*}$ & 0.3 \\
\hline & S68 & - & - & $3.0^{*}$ & $5.9 *$ \\
\hline & S72 & - & - & - & $2.9^{*}$ \\
\hline \multirow[t]{4}{*}{ Manipulation 1 (9.9 1/s) } & S33 & $17.5^{*}$ & $18.9^{*}$ & $18.9^{*}$ & $18.9^{*}$ \\
\hline & S38 & - & $1.5^{*}$ & $1.5^{*}$ & $1.5^{*}$ \\
\hline & S68 & - & - & 0.0 & 0.0 \\
\hline & S72 & - & - & - & 0.0 \\
\hline \multirow[t]{4}{*}{ Manipulation 2 (21.9 1/s) } & S33 & $10.9 *$ & $11.1^{*}$ & $11.1^{*}$ & $11.0^{*}$ \\
\hline & S38 & - & 0.2 & 0.2 & 0.1 \\
\hline & S68 & - & - & 0.1 & 0.2 \\
\hline & $\mathrm{S} 72$ & - & - & - & 0.1 \\
\hline
\end{tabular}

and S33 was the only pool with large areas deeper than $0.2 \mathrm{~m}$. Although increasing the discharge led to large increases in habitat deeper than $0.08 \mathrm{~m}$ in pools S38, S68, S72, and S85 (Fig. 4), pool S33 continued to offer the deepest habitat of all of the study pools for all of the evaluated flow conditions.

At $1.0 \mathrm{l} / \mathrm{s}$, horizontal and vertical velocity magnitudes remained near zero in all five of the study pools because of extremely low discharge (Figs. 5 and 6). At 9.9 1/s, only $\mathrm{S} 33$ and S38 continued to offer fish-size regions (ca. $0.3 \mathrm{~m}$ $\times 0.1 \mathrm{~m}$ ) with near-zero velocities in both the horizontal and vertical directions, while at 21.9 1/s, only S33 offered any large areas with near-zero horizontal and vertical velocities.

Given that most fish did not move from the pool in which they were stocked during the summer background flow $(1.0 \mathrm{l} / \mathrm{s})$, we found that the highest selection, as defined, occurred, somewhat surprisingly, in a few cells of pools S72 and S85 (Fig. 7). At the two higher flows, however, selection was highest in pool S33, with minor areas of use in pool S38. Grayling did not use the other pools for resting, but only for travelling through without stopping.

Habitat selection and avoidance was only evaluated for the manipulation flow conditions (9.9 1/s and $21.9 \mathrm{l} / \mathrm{s}$ ) for pools S33 and S38, since these were the only pools with fish frequently present. Fish showed significant selection for all three evaluated ecohydraulic parameters under both flow conditions. For both flows grayling significantly selected for depths in the range of 0.20 to $0.28 \mathrm{~m}$ (Fig. $8 \mathrm{a}, 8 \mathrm{~d}$ ), with fish showing significant local avoidance of depths between $0.10 \mathrm{~m}$ and $0.20 \mathrm{~m}$ at $9.9 \mathrm{l} / \mathrm{s}$ and $0.14 \mathrm{~m}$ to $0.18 \mathrm{~m}$ at $21.9 \mathrm{l} / \mathrm{s}$. Fish also showed significant selection for near-zero vertical velocities, in the range of $-0.02 \mathrm{~m} / \mathrm{s}$ to $0.02 \mathrm{~m} / \mathrm{s}$ at $9.91 / \mathrm{s}$ (Fig. 8 b) and $0.00 \mathrm{~m} / \mathrm{s}$ to $0.04 \mathrm{~m} / \mathrm{s}$ at $21.9 \mathrm{l} / \mathrm{s}$ (Fig. 8e). Fish showed local avoidance of all vertical velocities lower or higher than these ranges for the evaluated conditions.

We observed that Arctic grayling selected for two different ranges of horizontal velocities: 1) near-zero horizontal velocities in the range of $0.00 \mathrm{~m} / \mathrm{s}$ to $0.04 \mathrm{~m} / \mathrm{s}$ under both flow conditions, and 2) higher velocities in the range of $0.10 \mathrm{~m} / \mathrm{s}$ to $0.14 \mathrm{~m} / \mathrm{s}$ at $9.9 \mathrm{l} / \mathrm{s}$ (Fig. $8 \mathrm{c}$ ) and $0.12 \mathrm{~m} / \mathrm{s}$ to $0.20 \mathrm{~m} / \mathrm{s}$ at $21.9 \mathrm{l} / \mathrm{s}$ (Fig. $8 \mathrm{f}$ ).

\section{DISCUSSION}

The results of this study show that the design of pool S33 was strongly preferred by fish when compared with the other study pools. While fish were present in all the 

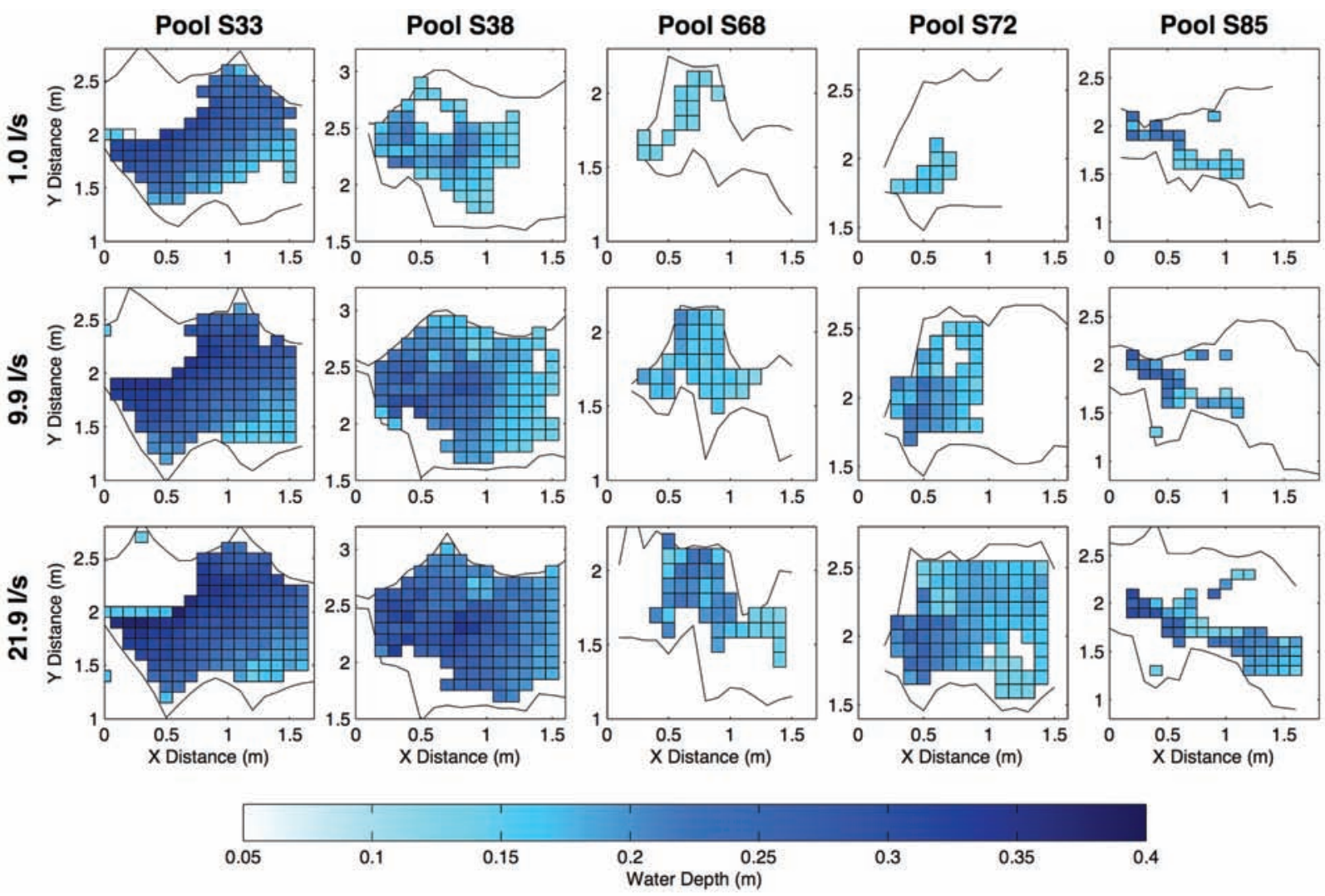

FIG. 4. Depth in the five study pools at the natural (1.0 1/s) and manipulated (9.9 and 21.9 1/s) flows. Black lines indicate pool banks. Data were only collected at locations with a minimum depth of $0.08 \mathrm{~m}$. Flow direction is from left to right.
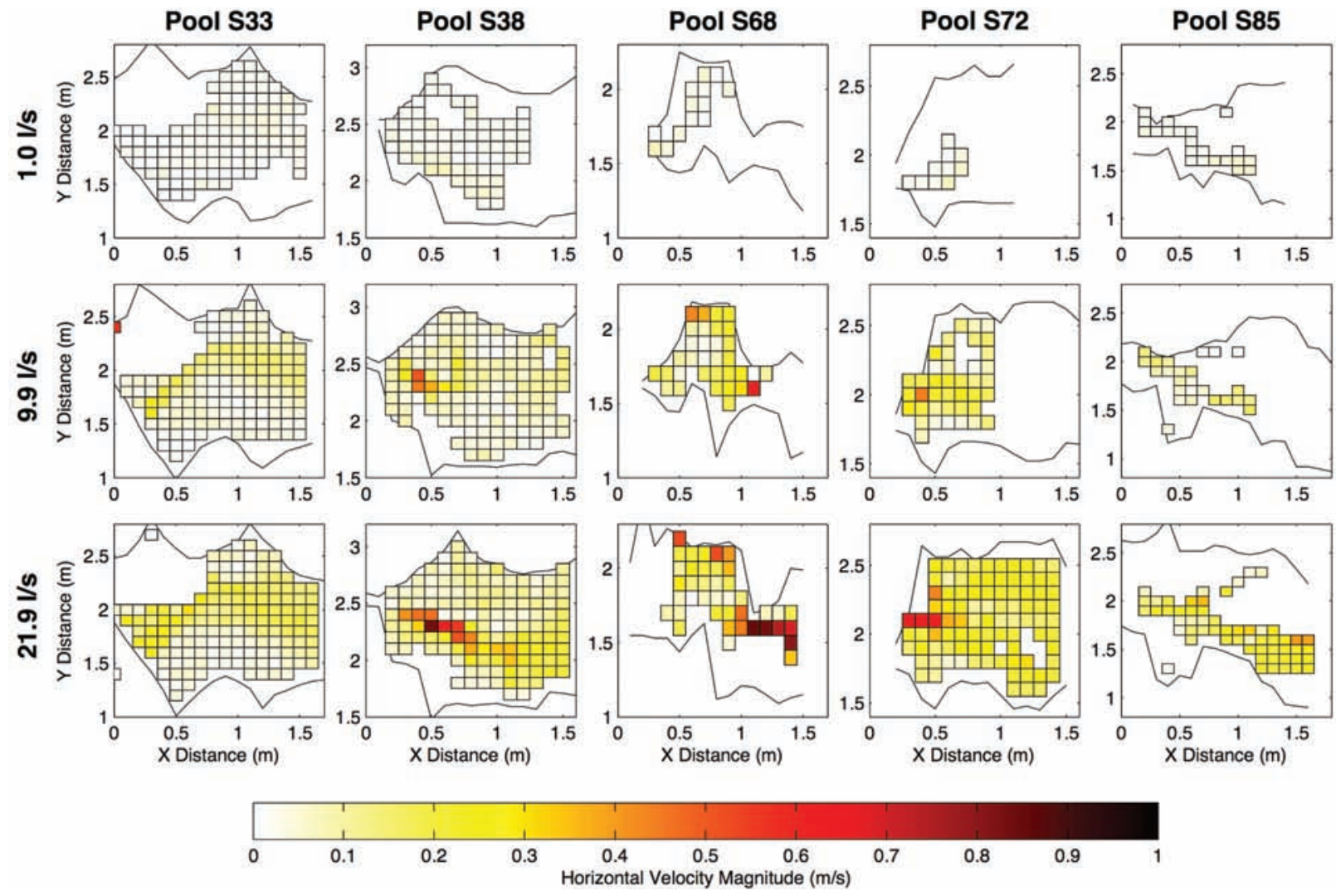

FIG. 5. Horizontal velocity magnitude in the five study pools at the natural (1.0 1/s) and manipulated (9.9 and $21.9 \mathrm{l} / \mathrm{s})$ flows. Black lines indicate pool banks. Data were only collected at locations with a minimum depth of $0.08 \mathrm{~m}$. Flow direction is from left to right. 

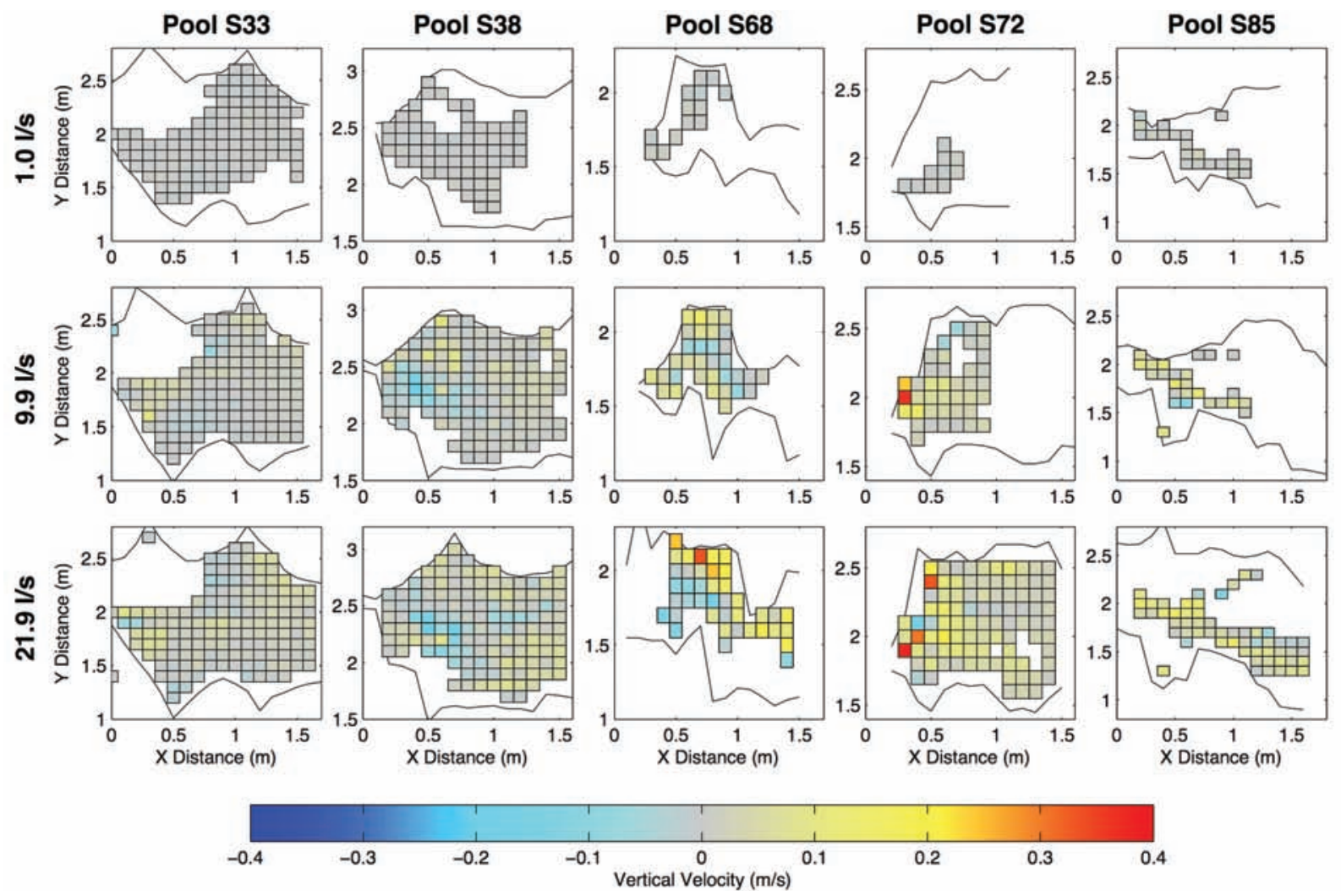

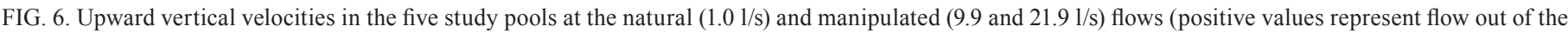
page). Black lines indicate pool banks. Data were only collected at locations with a minimum depth of $0.08 \mathrm{~m}$. Flow direction is from left to right.
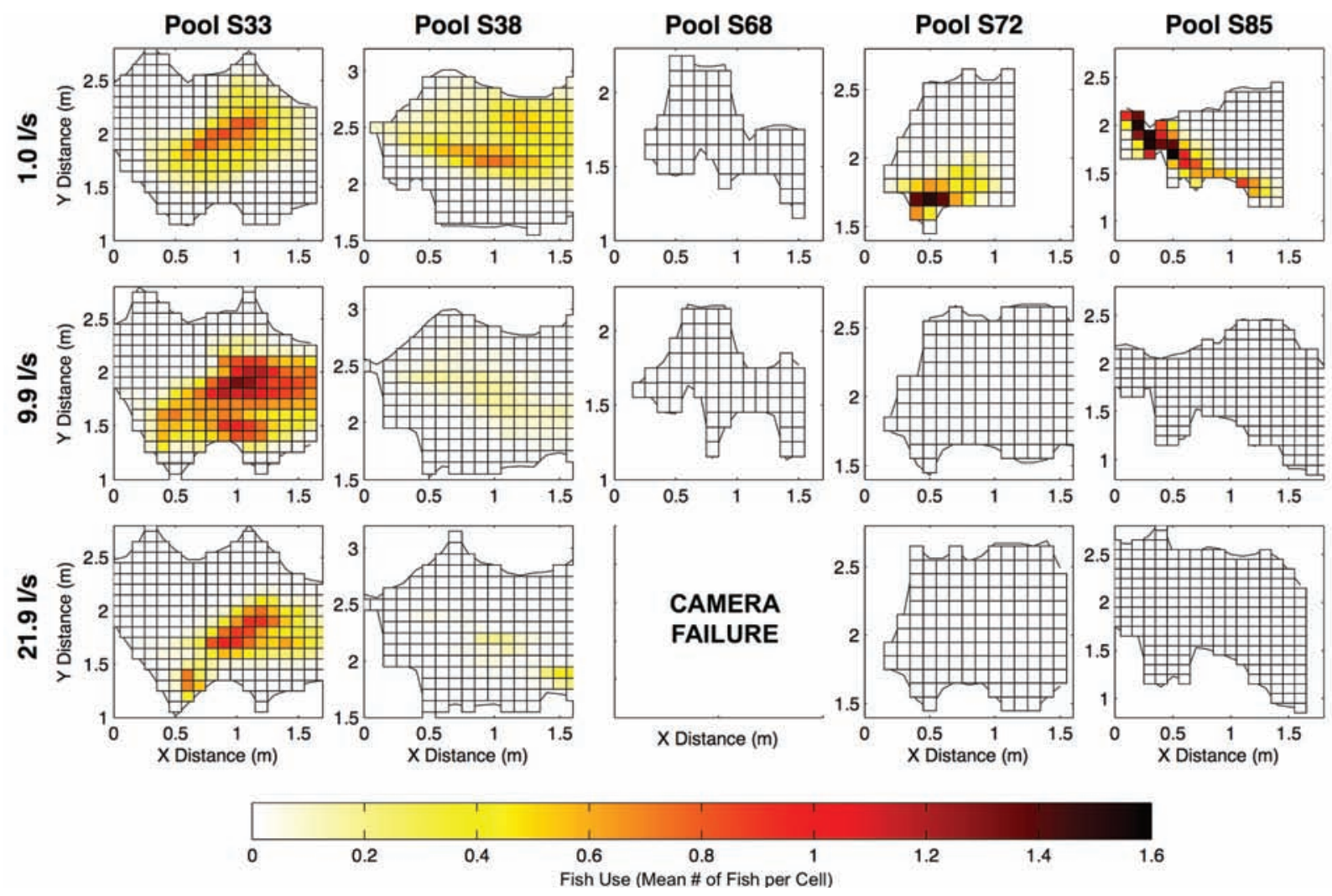

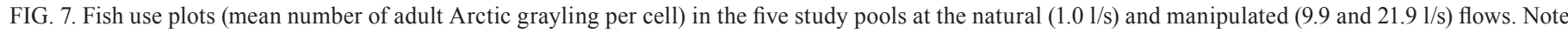

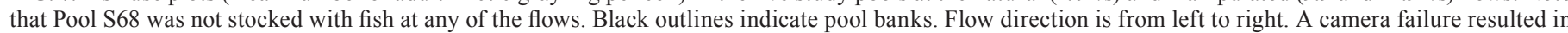
no data for S68 at 21.9 1/s. 
a) Depth $(9.9 \mathrm{l} / \mathrm{s})$

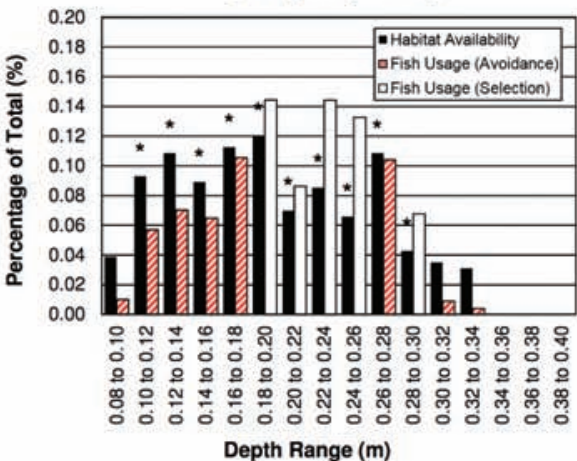

d) Depth $(21.9 \mathrm{l} / \mathrm{s})$

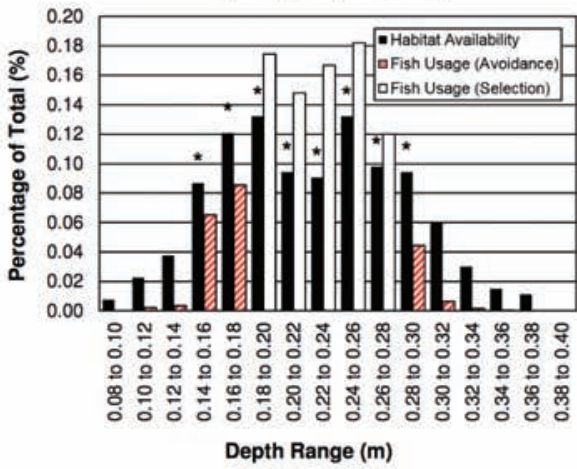

b) Vertical Velocity $(9.9 \mathrm{l} / \mathrm{s})$

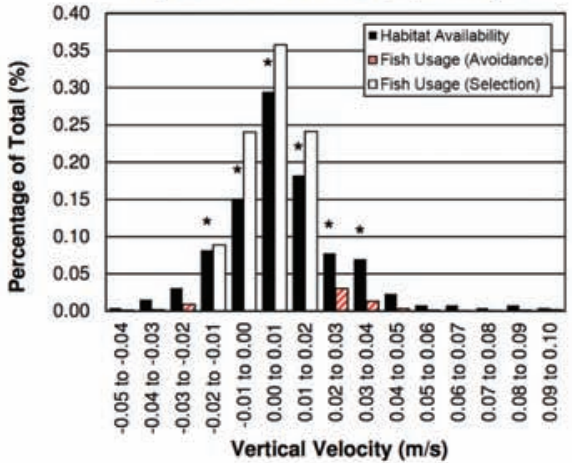

e) Vertical Velocity $(21.9 \mathrm{l} / \mathrm{s})$

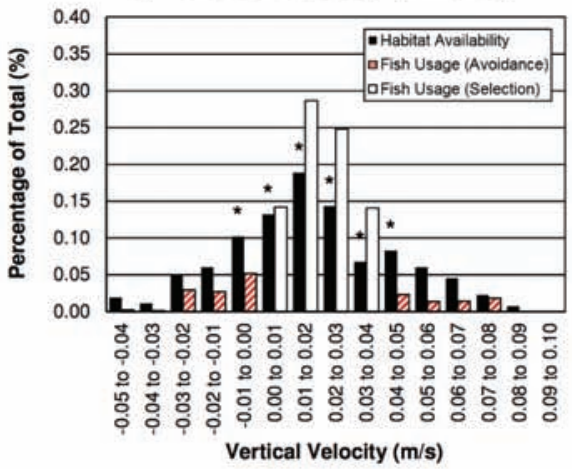

c) Horizontal Velocity $(9.9 \mathrm{l} / \mathrm{s})$

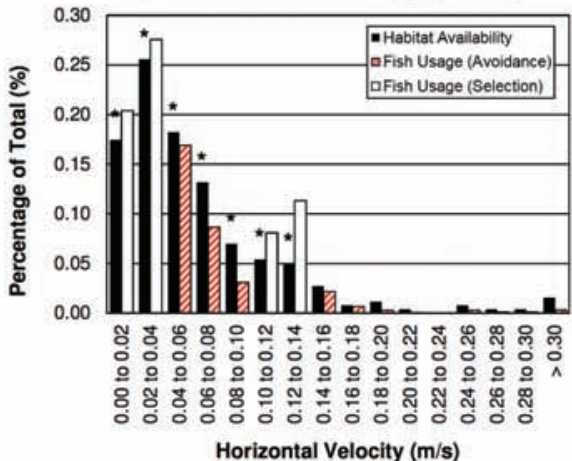

f) Horizontal Velocity $(21.9 \mathrm{l} / \mathrm{s})$

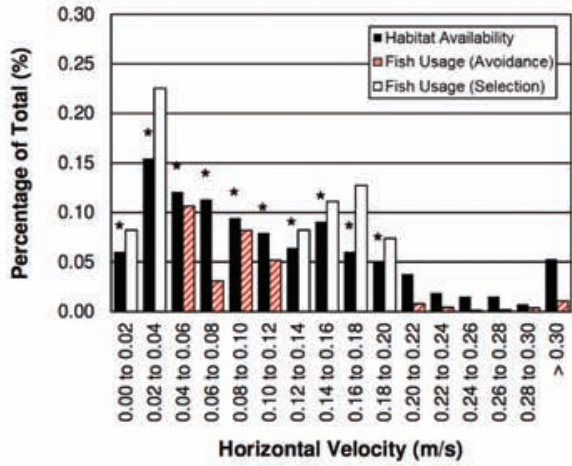

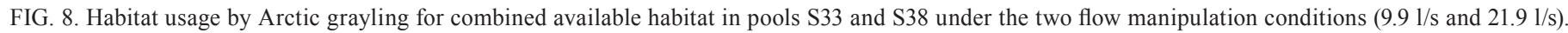
The $\operatorname{star}(*)$ denotes significant selection or avoidance at $p<0.05$.

stocked pools at $1.0 \mathrm{l} / \mathrm{s}$, their presence appeared to be because of limited mobility rather than preference, and conditions appeared sub-optimal for fish. This lack of mobility confirms that like other small Barrenland streams, WIS would provide poor summer habitat for adults when discharges decline to near zero (Craig and Poulin, 1975; Jones et al., 2003; Heim et al., 2016). At flows of 9.9 1/s and $21.9 \mathrm{l} / \mathrm{s}$ when fish were able to move freely throughout the study area, the fish actively selected S33 more often than the other pools.

The visual surveys used in this study were typically collected about an hour apart, and it should be assumed that the values from the surveys are serially correlated (Swihart and Slade, 1985). To avoid violating the independence of observations, Rogers and White (2007) suggest that it is possible to treat each fish rather than each sample as the experimental unit and reduce the degrees of freedom accordingly. However, in the case of this study, even if the degrees of freedom are reduced substantially (from ca. 100 to ca. 30) by using the number of fish as the number of experimental units, the major findings of this study remain significant.

Pools S33 and S38 offered relatively deep water compared to the other study pools, but S33 had a greater maximum depth and offered the most deep-water habitat. The maximum depth in S33 under the highest flow condition $(0.40 \mathrm{~m})$ is two-thirds of the recommended minimum depth of $0.6 \mathrm{~m}$ for resting pools designed for the closely related European grayling (FAO/DVWK, 2002). Jones and Tonn (2004) previously found that small (15-21 $\mathrm{mm}$ fork length) and large (32-57 $\mathrm{mm}$ fork length) young-of-year Arctic grayling had the highest selection for depths of $0.15 \mathrm{~m}$ and $0.55 \mathrm{~m}$, respectively, while DenBeste and McCart (1984) found that adult grayling in Alaskan streams selected for pools with an average depth of $0.8 \mathrm{~m}$. Qualitative observations at nearby streams during the spring spawning period showed adult Arctic grayling typically holding in locations with water depths greater than about $0.4 \mathrm{~m}$ when available.

Contrary to the findings of these previous studies, fish in WIS selected for depths in the range of $0.20 \mathrm{~m}$ to $0.30 \mathrm{~m}$ but made limited use of or even showed local avoidance of deeper habitat. We suspect that fish were not actually avoiding deeper water, but rather that a depth of ca. $0.20 \mathrm{~m}$ was deep enough and once met, fish began to select for other parameters (e.g., velocity, presence of cover, feeding proximity) that may not have coincided with the deepest locations. At the lowest discharge rate (1.0 l/s), the highest usage rates by fish (Fig. 7) coincided with the deepest water available in each pool (Fig. 4), which indicates that fish were clearly seeking deep water under the low-flow conditions. Therefore, we recommend that pools designed for use by Arctic grayling during low flow conditions incorporate downstream sills or scour holes (such as S33) to increase water depths. 
When compared with the recommended minimum dimensions for resting pools for European grayling (FAO/ DVWK, 2002), only S33 and S38 met the surface area recommendation of $1.4 \mathrm{~m}^{2}(1.4 \mathrm{~m}$ length $\times 1 \mathrm{~m}$ width $)$ under all flow conditions. S85 met the surface area recommendation at $21.9 \mathrm{l} / \mathrm{s}$ only. Although DenBeste and McCart (1984) found that total habitat use by an individual adult may be as small as $1.5 \mathrm{~m}^{2}$ in some mountain streams, Bishop (1971) found that spawning males typically defend an area of about $6.7 \mathrm{~m}^{2}$. This finding suggests that the minimum areal requirements may be dependent on intended use by fish and availability of food. Although a surface area of $1.4 \mathrm{~m}^{2}$ appeared to provide good resting habitat for Arctic grayling in WIS, we recommend that larger surface areas be considered for pool designs where spawning is an intended functional use.

Our qualitative observations at the study site showed that the Arctic graylings' preference for two different horizontal velocity ranges (Fig. 8c, 8f) could be explained by fish using near-zero velocity areas to rest and moving to higher velocity $(0.12 \mathrm{~m} / \mathrm{s}$ to $0.20 \mathrm{~m} / \mathrm{s})$ areas to feed. These observations are consistent with the findings of DenBeste and McCart (1984) who observed grayling resting in pools with near-zero velocity located adjacent to swift water $(>0.5 \mathrm{~m} / \mathrm{s})$, and with theories on microhabitat use for feeding (Hughes and Dill, 1990; Hughes, 1992a, b). We recommend that engineered streams designed for Arctic grayling aim to provide both near-zero and feeding velocities under design flow conditions, while avoiding velocities above $0.20 \mathrm{~m} / \mathrm{s}$ in areas designed for resting.

The notched rock-weirs upstream of S33 and S38 were able to achieve this objective at design flows by causing flow to enter the pools as a jet near the channel centreline (see Fig. 5), rather than spanning the entire pool width like a traditional weir. This design produced a higher velocity region for feeding (along the centerline of the channel) and lower velocity eddies for resting (near the banks). Notched rock-weirs offer additional ecohydraulic benefits, since the centre notch provides low-flow fish passage and flood flows can be passed over the top of the weir. We recommend that designers ensure that the notch is wide enough to prevent fish or debris from becoming trapped.

To our knowledge this is the first study to evaluate vertical velocity selection by Arctic grayling. A strong selection for near-zero vertical velocities was identified in this study and we recommend this topic for future research, since it appears to be an important parameter to consider in resting pool designs.

Despite some limitations to this study, (e.g., possible crowding in selected pools), the velocities and depths used by the fish in the study pools represented a small portion of the total available habitat within WIS, and there were clearly specific areas that were selected for or avoided by fish. While fish hydrodynamics can be expected to have some impact on downstream velocity fields (e.g., Hemelrijk et al., 2015), they were not considered in this study.

\section{Monitoring with Video Cameras}

We found that the use of video cameras to record the positions of fish, combined with detailed velocity and depth measurements, allowed for a rapid, quantitative assessment of fish habitat use at the study site. While many previous studies have used underwater cameras to monitor fish (e.g., Carlson and Quinn, 2005; Ebner et al., 2015; Wilson et al., 2015), few have attempted to combine video data with spatial measures of depth or velocity, and we are not aware of other field studies that have used video cameras mounted above pools to evaluate fish position in streams.

We did not use a polarizing filter on the camera lenses during this study, but we recommend that future studies use these filters to reduce reflections from the water surface, which occasionally made it more difficult to identify fish. We also did not correct for refraction due to the water surface because the study pools were shallow and the angle of incidence from the cameras was typically close to perpendicular; thus, the impact on fish position was small for the current study.

Traditional methods of fish monitoring such as radiofrequency identification (RFID) or radio-telemetry have some drawbacks. For example, the method used to capture fish can result in biased samples (Rogers and White, 2007) that are not representative of the population as a whole (e.g., gill nets may capture more mobile fish). Using our method, it is not necessary to capture fish if a sufficient population already exists in the system.

Traditional methods also require that transmitters be physically attached to the fish. Bridger and Booth (2003) and Rogers and White (2007) discuss many of the challenges associated with physically implanting transmitters in fish, which include long recovery periods, adverse impacts to swimming performance, infection after implantation, and even mortality. Because the current method does not require that transmitters be implanted in fish, these risks are not present.

Many previous studies have used metrics with low spatial resolution, such as averaged velocity values or sampling cells much larger in size than the fish being studied (e.g., Hughes and Dill, 1990; Ayllón et al., 2010). Figure 5 demonstrates that for all the study pools high variability in velocity occurred within small spatial areas, sometimes even between adjacent cells. We recommend that when selecting a sampling cell size, researchers consider both site-specific velocity variability (because of the hydraulic characteristics of the pool) and the size of the fish being observed to ensure that velocities at fish positions are accurately reported.

We found it was possible to reproduce the seasonal range of flows seen in Barrenland streams by using a pump to augment the flow. This method allowed us to collect measurements over a wide range of flow conditions in a short period of time rather than requiring multiple site visits during different periods of the hydrologic cycle. For remote sites like ours, not having to make multiple site visits can 
mean significant travel cost savings. Another major benefit is that this method allows velocity measurements to be collected outside of sensitive fishery periods (e.g., spawning and migration). When combined with continuous flow monitoring, video data collected during these periods can be used to provide quantitative measures of fish habitat use without negatively impacting fish.

We demonstrated that combining inexpensive video cameras with ADV technology to quantify depth and velocity selection can be a rapid and effective method for evaluating engineered streams and fishways, particularly for small sites or remote locations. The technique could also be used to evaluate fish habitat use in natural streams prior to construction to help establish reference reaches and determine design criteria specific to local fish populations, by incorporating it into before-after-control-impact (BACI) evaluations (Stewart-Oaten et al., 1986). However, using the current techniques to evaluate fish position is limited to clear water with relatively shallow water depths and sufficient light conditions.

\section{CONCLUSIONS}

This study used a novel technique that combined streamscale flow manipulations, detailed three-dimensional hydraulic measurements, and inexpensive video cameras to evaluate depth and velocity use by Arctic grayling in an engineered stream located in a remote location and logistically challenging environment. For the flows expected in WIS during the spring spawning period, we found that S33 offered the best habitat since it incorporated deep water and large areas for resting and feeding.

Within the study pools, Arctic grayling selected for locations with depths between $0.20 \mathrm{~m}$ and $0.30 \mathrm{~m}$ and near-zero vertical velocities $(-0.02 \mathrm{~m} / \mathrm{s}$ to $0.04 \mathrm{~m} / \mathrm{s})$. Fish selected near-zero horizontal velocities $(0.00 \mathrm{~m} / \mathrm{s}$ to $0.04 \mathrm{~m} / \mathrm{s})$ for resting and higher velocities $(0.12 \mathrm{~m} / \mathrm{s}$ to $0.20 \mathrm{~m} / \mathrm{s}$ ) for feeding. In contrast, grayling tended to show local avoidance of areas with horizontal velocities above $0.20 \mathrm{~m} / \mathrm{s}$ or vertical velocities above $0.04 \mathrm{~m} / \mathrm{s}$.

Our study contributes towards the development of size, depth, velocity, and design criteria for effective pools for Arctic grayling. This information can promote effective designs for habitat compensation and fish passage projects for Arctic grayling, which will become increasingly important with ongoing economic development (e.g., mining, road construction) in northern Canada and Alaska. While fish in this study showed clear selection for depth and velocities, the findings may be site-specific and should be combined with findings of additional studies to develop generalized or regional ecohydraulic design guidelines for Arctic grayling.

\section{ACKNOWLEDGEMENTS}

This research is part of a project that received research ethics approval in 2011 from the University of Alberta Animal Care and Use Committee under "Improving habitat connectivity to enhance productive capacity of Arctic freshwater ecosystems" (No. 688/03/12). The project was renewed in 2012 as No. $688 / 03 / 13$ and also under "Enhancing productive capacity and understanding biodiversity of Arctic freshwater ecosystems" (No. 764/03/13). It was subsequently renewed as AUP00000034 in 2013. The authors would like to thank the staff of the DDMI Environment Department for logistical support and all of the volunteers who assisted with fieldwork during the 2014 field season. Funding for this project was provided by the Natural Sciences and Engineering Research Council of Canada (NSERC) and Diavik Diamond Mines Inc. under an NSERC Collaborative Research and Development grant. Additional financial support was provided by the Province of Alberta, Aboriginal Affairs and Northern Development Canada, and the Canadian Circumpolar Institute at the University of Alberta.

\section{REFERENCES}

Ayllón, D., Almodóvar, A., Nicola, G.G., and Elvira, B. 2010. Ontogenetic and spatial variations in brown trout habitat selection. Ecology of Freshwater Fish 19(3):420-432. https://doi.org/10.1111/j.1600-0633.2010.00426.x

Baki, A.B.M., Zhu, D.Z., and Courtice, G. 2012. Hydraulic geometry and resistance to flow in headwater streams in the Northwest Territories, Canada. Canadian Journal of Civil Engineering 39(12):1252-1263.

https://doi.org/10.1139/12012-113

Bishop, F.G. 1971. Observations on spawning habits and fecundity of the Arctic grayling. The Progressive Fish-Culturist (currently the North American Journal of Aquaculture) 33(1):12-19. https://doi.org/10.1577/1548-8640(1971)33[12:OOSHAF] 2.0.CO;2

Bradski, G. 2000. The OpenCV library. Dr. Dobbs Open Source. http://www.drdobbs.com/open-source/the-opencv-library/ 184404319

Bridger, C.J., and Booth, R.K. 2003. The effects of biotelemetry transmitter presence and attachment procedures on fish physiology and behaviour. Reviews in Fisheries Science 11(1):13-34. https://doi.org/10.1080/16226510390856510

Bunt, C.M., Castro-Santos, T., and Haro, A. 2012. Performance of fish passage structures at upstream barriers to migration. River Research and Applications 28(4):457-478. https://doi.org/10.1002/rra.1565

Cahill, C.L., Erwin, A.C., Howland, K.L., Hulsman, M.F., Lunn, B.D., Noddin, F., Tonn, W.M., Baki, A.B., Courtice, G., and Zhu, D.Z. 2015. Assessing responses of fish to habitat enhancement in Barrenland streams of the Northwest Territories. North American Journal of Fisheries Management 35(4):755 - 764. https://doi.org/10.1080/02755947.2015.1044626 
Carlson, L.D., and Quinn, M.S. 2005. Evaluating the effectiveness of instream habitat structures for overwintering stream salmonids: A test of underwater video. North American Journal of Fisheries Management 25(1):130-137. https://doi.org/10.1577/M03-196.1

CCEA (Canadian Council on Ecological Areas). 2014. Ecozones of Canada [Map]. Version 2014.02. (ca. 1:1,000,000).

Clay, C.H. 1995. Design of fishways and other fish facilities, 2nd ed. Boca Raton, Florida: Lewis Publishers. 256 p.

Copeland, R.R., McComas, D.N., Thorne, C.R., Soar, P.J., Jonas, M.M., and Fripp, J.B. 2001. Hydraulic design of stream restoration projects. ERDC/CHL TR-01-28. Washington, D.C.: United States Army Corps of Engineers.

Courtice, G., Baki, A.B.M., Zhu, D.Z., Cahill, C., and Tonn, W.M. 2014. Stream modifications to enhance system connectivity for fish habitat compensation: A case study in the Barrenlands region of Canada. Canadian Journal of Civil Engineering 41(7):650-659. https://doi.org/10.1139/cjce-2014-0012

_ 2016. Stream habitat connectivity in the Canadian Arctic: An on-site approach to design and construction. Canadian Journal of Civil Engineering 43(2):139-150. https://doi.org/10.1139/cjce-2015-0241

Craig, P.C., and Poulin, V.A. 1975. Movements and growth of Arctic grayling (Thymallus arcticus) and juvenile Arctic char (Salvelinus alpinus) in a small Arctic stream, Alaska. Journal of the Fisheries Research Board of Canada 32(5):689-697. https://doi.org/10.1139/f75-088

DenBeste, J., and McCart, P. 1984. Overview of studies of the longterm effects of the Trans Alaska Pipeline System on fish and aquatic habitats. Anchorage, Alaska: Aquatic Environments Incorporated.

Ebner, B.C., Fulton, C.J., Cousins, S., Donaldson, J.A., Kennard, M.J., Meynecke, J.-O., and Schaffer, J. 2015. Filming and snorkelling as visual techniques to survey fauna in difficult to access tropical rainforest streams. Marine \& Freshwater Research 66(2):120-126. https://doi.org/10.1071/MF13339

Environment Canada. 1991. Canadian climate normals 1961-1990. Ottawa: Environment and Climate Change Canada. http://climate.weather.gc.ca/climate_normals/index_e.html

FAO/DVWK (Food and Agriculture Organization of the United Nations/Deutscher Verband für Wasserwirtschaft und Kulturbau e.V.). 2002. Fish passes: Design, dimensions, and monitoring. Rome: FAO. 119 p. http://www.fao.org/3/y4454e/y4454e00.htm

GeoBase. National Hydro Network - NHN - GeoBase series. Ottawa: Natural Resources Canada. http://www.geobase.ca/geobase/en/data/nhn/index.html

Harrelson, C.C., Rawlins, C.L., and Potyondy, J.P. 1994. Stream channel reference sites: An illustrated guide to field technique. General Technical Report RM-245. Fort Collins, Colorado: U.S. Department of Agriculture, Forest Service, Rocky Mountain Forest and Range Experiment Station. 61 p.
Heim, K.C., Wipfli, M.S., Whitman, M.S., Arp, C.D., Adams, J., and Falke, J.A. 2016. Seasonal cues of Arctic grayling movement in a small Arctic stream: The importance of surface water connectivity. Environmental Biology of Fishes 99(1):49-65.

https://doi.org/10.1007/s10641-015-0453-X

Hemelrijk, C.K., Reid, D.A.P., Hildenbrandt, H., and Padding, J.T. 2015. The increased efficiency of fish swimming in a school. Fish and Fisheries 16(3):511-521. https://doi.org/10.1111/faf.12072

Hughes, N.F. 1992a. Ranking of feeding positions by driftfeeding Arctic grayling (Thymallus arcticus) in dominance hierarchies. Canadian Journal of Fisheries and Aquatic Sciences 49(10):1994-1998. https://doi.org/10.1139/f92-222

. 1992b. Selection of positions by drift-feeding salmonids in dominance hierarchies: Model and test for Arctic grayling (Thymallus arcticus) in subarctic mountain streams, interior Alaska. Canadian Journal of Fisheries and Aquatic Sciences 49(10):1999-2008.

https://doi.org/10.1139/f92-223

Hughes, N.F., and Dill, L.M. 1990. Position choice by driftfeeding salmonids: Model and test for Arctic grayling (Thymallus arcticus) in subarctic mountain streams, interior Alaska. Canadian Journal of Fisheries and Aquatic Sciences 47(10):2039-2048.

https://doi.org/10.1139/f90-228

Jones, D.R., Kiceniuk, J.W., and Bamford, O.S. 1974. Evaluation of the swimming performance of several fish species from the Mackenzie River. Journal of the Fisheries Research Board of Canada 31(10):1641 - 1647. https://doi.org/10.1139/f74-206

Jones, N.E., and Tonn, W.M. 2004. Resource selection functions for age-0 Arctic grayling (Thymallus arcticus) and their application to stream habitat compensation. Canadian Journal of Fisheries and Aquatic Sciences 61(9):1736-1746. https://doi.org/10.1139/f04-116

Jones, N.E., Tonn, W.M., Scrimgeour, G.J., and Katopodis, C. 2003. Ecological characteristics of streams in the Barrenlands near Lac de Gras, N.W.T., Canada. Arctic 56(3):249-261. https://doi.org/10.14430/arctic620

Katopodis, C., Kells, J.A., and Acharya, M. 2001. Nature-like and conventional fishways: Alternative concepts? Canadian Water Resources Journal 26(2):211-232. https://doi.org/10.4296/cwrj2602211

MacNeill, W.S., and Strong, G. 2004. Stream fish habitat design for the West Island Stream at the Diavik Diamond Mine. Report prepared by Dillon Consulting for Diavik Diamond Mines Inc., 1420, 6A St. NW, Calgary, Alberta T2M 3G7.

MEA (Millennium Ecosystem Assessment). 2005. Ecosystems and human well-being: Synthesis. Washington, D.C.: Island Press.

Noddin, D.F. 2017. Fish movement through a nature-like fishpass within a small Arctic stream. MSc thesis, University of Alberta, Edmonton. 
Northcote, T.G. 1995. Comparative biology and management of Arctic and European grayling (Salmonidae, Thymallus). Reviews in Fish Biology and Fisheries 5(2):141-194. https://doi.org/10.1007/BF00179755

Ramsey, J., and Walker, D.R. 2012. West Island fish habitat compensation works: Design brief. Report prepared by Golder Associates for Diavik Diamond Mines Inc., Suite 2300, 6395 Ave. SW, Calgary, Alberta T2P 0M9.

Rogers, K.B., and White, G.C. 2007. Analysis of movement and habitat use from telemetry data. Chapter 14 in: Guy C.S., and Brown M.L., eds. Analysis and interpretation of freshwater fisheries data. Bethesda, Maryland: American Fisheries Society. 625-676.

Rosenfeld, J. 2003. Assessing the habitat requirements of stream fishes: An overview and evaluation of different approaches. Transactions of the American Fisheries Society 132(5):953-968.

https://doi.org/10.1577/T01-126

SonTek/YSI. 2007. FlowTracker handheld ADV technical manual. San Diego, California: SonTek/YSI Inc.
Stewart-Oaten, A., Murdoch, W.W., Parker, K.R. 1986. Environmental impact assessment: "Pseudoreplication" in time? Ecology 67(4):929-940. https://doi.org/10.2307/1939815

Swihart, R.K., and Slade, N.A. 1985. Testing for independence of observations in animal movements. Ecology 66(4):1176-1184. https://doi.org/10.2307/1939170

USDA/NRCS (United States Department of Agriculture/Natural Resources Conservation Service). 2007. Stream restoration design. National Engineering Handbook 654.

https:/www.nrcs.usda.gov/wps/portal/nrcs/detail/national/ water/manage/restoration/?cid=stelprdb1044707

Wedel, J., Olding, B., and Palmer, M. 1988. An overview study of the Coppermine River Basin. Yellowknife, N.W.T.: Environment Canada.

Wilson, K.L., Allen, M.S., Ahrens, R.N., and Netherland, M.D. 2015. Nonlinear and density-dependent fish habitat selection across physiochemical gradients in an invasive macrophyte habitat. Environmental Biology of Fishes 98(6):1525 - 1539. https://doi.org/10.1007/s10641-015-0379-3 